\title{
MOLECULAR CLOCK DIVERGENCE ESTIMATES AND THE FOSSIL RECORD OF CETARTIODACTYLA
}

\author{
JESSICA M. THEODOR \\ Department of Geology, Illinois State Museum, Springfield 62703, <jtheodor@museum.state.il.us>
}

\begin{abstract}
Molecular clock estimates of divergence times for artiodactyls and whales vary widely in their agreement with the fossil record. Recent estimates indicate that the divergence of whales from artiodactyls occurred $60 \mathrm{Ma}$, a date which compares well with the first appearances of fossil whales around $53.5 \mathrm{Ma}$, and artiodactyls at $55 \mathrm{Ma}$. Other estimates imply significant gaps in the fossil record. A date of $65 \mathrm{Ma}$ for the divergence of Suidae and Ruminantia predates the appearance of Ruminantia by over 10 million years, and an estimate of $58 \mathrm{Ma}$ for the divergence of Suidae from Cetacea implies a gap of over 20 million years. Further, although a molecular clock estimate has not been reported, the hypothesis that hippos are the closest living relatives of the whales implies a potential ghost lineage for hippos of over 40 million years. There are only two living species of hippos, and their fossil record is sparse, while cetaceans and other artiodactyls are speciose and have rich fossil records. A 40-million-year gap in the fossil record of hippos could be explained by several possibilities: inadequate biogeographic sampling, taphonomic biases, or undifferentiated primitive morphology. Similarly, a number of possible problems may exist in the molecular data: rate variation in the genes sampled, the low numbers of genes examined, and insufficient age calibrations. In addition, there are potential problems in molecular phylogeny estimation, such as long branch attraction and inappropriate taxonomic sampling. Additional estimates of divergence times among living taxa should provide a broader framework for comparison with the fossil record and provide information to help identify which of these factors are causing conflict.
\end{abstract}

\section{INTRODUCTION}

$\mathrm{R}^{\mathrm{B}}$ ECENT MOLECULAR phylogenetic work on the relationships of placental mammals show strong support for close relationship between whales (Cetacea) and artiodactyls, with numerous studies nesting Cetacea deep within a paraphyletic Artiodactyla, in most cases sister taxon to the Hippopotamidae (Gatesy, 1997, 1998; Gatesy et al., 1996, 1999; Graur and Higgins, 1994; Milinkovitch et al., 1998; M. A. Nikaido et al., 1999). New fossil discoveries of postcranial material of early whales show they share what had been thought to be a key synapomorphy of artiodactyls, the double-trochleated astragalus (Gingerich et al., 2001; Thewissen et al., 2001). Although these finds provide evidence supporting the close relationship of whales and artiodactyls, there is as yet no fossil evidence that supports a sister-taxon relationship between the whales and the family Hippopotamidae. However, if correct, this hypothesis has radical implications for the fossil record of cetaceans and artiodactyls and the history of divergences within the Cetartiodactyla, because it implies that there are several ghost lineages of considerable length, either yet to be found in fossil deposits, or lurking in museum drawers and undetectable by morphological methods. In order to evaluate that possibility, molecular clock estimates of divergence times could point to lineages in need of further study, but the reliability of such estimates for Cetartiodactyla is unknown. Therefore, molecular clock estimates for more nodes within Cetartiodactyla must be calculated and compared with the known fossil record.

The fossil record for Artiodactyla and Cetacea accords well with published molecular clock estimates for the divergence of the two groups: the oldest known whale, Himalayacetus, is early Eocene in age, 53.5 Ma (Bajpai and Gingerich, 1998), and the oldest artiodactyl, Diacodexis, known from the earliest Eocene, $55 \mathrm{Ma}$ (Gingerich, 1989), are both slightly younger than the molecular clock estimate of $60 \mathrm{Ma}$ (Arnason and Gullberg, 1996). The most recent molecular clock estimate of the divergence of odontocete and mysticete whales around 34-35 Ma also agrees well with the fossil record (M. Nikaido et al., 2001). However, estimates of divergence times for other subgroups are scarce, and some estimates of suid divergence from ruminants predate the oldest records of either order (Kumar and Hedges,
1998). The hippopotamid/cetacean relationship is especially difficult to reconcile, given that whales appear in the early Eocene and the oldest hippopotamid fossil is known from the mid-Miocene (Behrensmeyer et al., 2002), 15.6-15.8 Ma, a gap of 40 million years. This gap is somewhat lessened, to about 10 million years, if the fossil anthracotheres are closely related to the hippopotamids (Colbert, 1935), as they have a long fossil record going back to the middle Eocene. However, the morphological evidence linking anthracotheres and hippos is not strong, and it has been suggested that hippopotamids may be derived from other lineages, including the tayassuids (Pickford, 1983) and the cebochoerids (Pearson, 1927). Such a relationship would mean that whales diverged genetically from hippopotamids or their close relatives before the first appearance of whale fossils, and hence over 53 million years ago.

This study was undertaken to examine additional molecular clock estimates of divergence times within the Artiodactyla and Cetacea, and compare those divergence times with the fossil record, to better understand the causes of conflict between the molecular data and the fossil record.

\section{METHODS}

The data used include the cytochrome b (cytb) mitochondrial gene sequence data (1,143 base pairs, 63 taxa) and the kappa casein (kcas) nuclear gene sequence data (679 base pairs, 33 taxa) from the WHIPPO-2 data matrix (Gatesy et al., 1999).

Each data set was tested for clocklike behavior using relative rate tests (Fitch, 1976; Sarich and Wilson, 1967; Tajima, 1993) and likelihood ratio tests (Felsenstein, 1981; Huelsenbeck and Crandall, 1997; Huelsenbeck and Rannala, 1997; D. L. Swofford et al., 1996). The substitution models selected for the likelihood ratio tests were selected using hierarchical likelihood ratio tests to select an appropriate model, as implemented in Modeltest 3.06 (Posada and Crandall, 1998). The likelihood ratio tests were performed on three trees, using PAUP*: the best likelihood tree calculated using the selected substitution model, the pruned shortest topology and the shortest parsimony tree constrained for monophyletic Artiodactyla (Gatesy, 1999). Likelihood ratio tests were calculated for the full data sets and also after pruning the taxa that violated relative rate tests for clocklike behavior.

Relative rate tests were performed using MEGA version 2.1 
TABLE 1 -Calibration dates used in molecular clock analyses.

\begin{tabular}{llcl}
\hline \hline \multicolumn{1}{c}{ Divergence } & \multicolumn{1}{c}{ Fossil taxon } & Age (Ma) & Reference \\
\hline 1 Mytsiceti-Odontoceti Cetacea & Llanocetus, first mysticete & 34.2 & Fordyce, 1989 \\
2 Pinnipedia-Procyonidae Carnivora & Enaliarctos, first pinniped & $27-30$ & Berta et al., 1989 \\
3 Ursidae-Canidae Carnivora & Cephalogale, first ursid & $37-40$ & Wayne et al., 1991 \\
4 Dugongidae-Trichechidae Sirenia & Protosiren, first dugongid & 45 & Domning and Gingerich, 1994 \\
5 within Muridae Rodentia & Mus and Rattus & 12 & Jacobs and Downs, 1994 \\
6 Ruminantia-Camelidae Artiodactyla & Pseudamphimeryx, first ruminant & $49-55$ & Savage and Russell, 1983 \\
7 Giraffidae-Cervidae Artiodactyla & Canthumeryx & 17.8 & Drake et al., 1988 \\
8 Antilocapridae-Giraffidae Artiodactyla & Merycodontids, Merycodus & 17.3 & Janis et al., 1988 \\
9 Giraffida-Bovidae Artiodactyla & Eotragus & 18.3 & Solounias et al., 1995 \\
\hline
\end{tabular}

(Kumar et al., 2001) for all pairs of taxa in each data set, using the armadillo (Dasypus novemcinctus) sequence as outgroup for the tests of the cytb data set, and the guinea pig (Cavia) sequence for the kcas data set. Likelihood scores for likelihood ratio tests, and Kimura 2 parameter (K2P) distance values for all pairs of taxa in each data set were computed using PAUP* 4.0b10 (David L. Swofford, 2002).

Clock calibrations were done using a number of single point estimates, shown in Table 1. Estimates were also calculated for regression equations based on all calibrations, but are omitted because a significant regression equation for the calibrations could be calculated only by omitting most of the calibration points.

\section{RESULTS}

Both data sets contained a number of pairs of taxa that differed significantly, at the 0.05 or 0.01 level, from the null hypothesis of clocklike behavior under a relative rate test. Likelihood ratio tests on both data sets, both including and excluding the taxon pairs that violated the relative rates tests, showed that the data sets violated the assumption of clocklike behavior on all three trees tested. This indicates that although a number of pair-wise distances do not violate a relative rates test, they do not pass the likelihood ratio test - a more conservative but topologically constrained test that is dependent on a particular model of sequence evolution - and all of these results should be viewed with caution. It should be noted that the pair-wise comparisons are non-independent, an additional reason for cautious interpretation of these results.

The estimated molecular clock divergence dates for the nuclear kappa casein gene and the mitochondrial cytochrome b gene are in Tables 2 and 3, respectively. The means listed represent dates calculated from the mean of all pair-wise K2P distances for all taxa included in the groups, where those comparisons did not violate the molecular clock assumption based on the relative rates test. The tables also include standard errors for the clock estimates, based only on the standard errors of the K2P distance data, and not including calibration error. Although methods exist for calculating stratigraphic confidence intervals on taxon ranges (Marshall, 1990), they rely on a model of fossil preservation that is applicable only to marine rocks, and not to fossils preserved in terrestrial rocks, which are much less common.

A calibration based on linear regression of calibration points was abandoned because there was no strong linear relationship between the calibration dates and $\mathrm{K} 2 \mathrm{P}$ distance values, nor was there a linear relationship between log calibration date and $\log$ $\mathrm{K} 2 \mathrm{P}$ distance.

The resulting estimates vary widely depending on which calibration is used, a pattern also found in other studies (Huchon et al., 2000; Norman and Ashley, 2000; Soltis et al., 2002; Brochu, this volume). A consistent pattern of divergence timing is evident, however-invariably, the order of divergences begins with the oldest divergence of Camelidae, followed by Suidae, Tayassuidae, and Hippopotamidae. Estimates for Tragulidae, Odontoceti, and
Mysticeti are generally younger and close together in time, followed by a still more recent divergence of cervids, bovids, antilocaprids and giraffids.

For the kappa casein sequence, most of the external calibrations violated the relative rates test. The sole external calibration point yields clearly erroneous results: the estimates, based on the Mus/Rattus divergence (calibration 5) are younger than the fossil record for most of the groups analyzed. The calibration based on the odontocete-mysticete divergence (calibration 1) gives by far the oldest estimates for the kcas gene, predicting several divergences older than $300 \mathrm{Ma}$, earlier than the oldest fossil evidence of Mammalia, much less cetaceans or artiodactyls.

The internal artiodactyl calibrations yielded divergence estimates that are closer to the first appearances known from the fossil record. The calibration based on the ruminant-camelid divergence (calibration 6) predicted divergences of giraffids from bovids and cervids about $15 \mathrm{Ma}$, younger than the known first appearances of giraffids (17.8 Ma) and bovids (18.3 Ma) and also predicted a younger divergence for mysticetes from odontocetes than is known from the fossils. The predicted divergences of suids, tayassuids and tragulids are all older than known from the fossil record, but less severely than some of the other calibrations. The divergence dates for hippopotamids from the whale taxa are, with the exception of the odontocete/mysticete and the antilocaprid/giraffid calibration, considerably younger than the first appearances of whales, and for the Mus/Rattus calibration, younger than the first appearance of fossil hippos.

The calibrations for the cytochrome $b$ sequence show fewer extreme molecular clock estimates for this gene. The deepest divergences are predicted by the dugong-manatee calibration (calibration 4), but these are much less deep in time than the deepest divergences predicted by the kcas gene-the oldest predicted divergence based on cyt $b$ extends back in time about $80 \mathrm{Ma}$, in the Late Cretaceous rather than the Carboniferous as predicted by the kcas gene. The youngest divergences are also predicted by the Mus/Rattus calibration. Most of the other calibrations yield divergence time estimates that are younger than the first appearance datum for that taxon in the fossil record (Table 4) — such as the divergence dates for camelids from other artiodactyl taxa, which are much younger than the known record of camels, which are found in the fossil record in the early Eocene, dating back to 45-46 Ma.

\section{DISCUSSION}

The fact that so many of the calibration points yield dates that are either extraordinarily old (the odontocete/mysticete calibration for the kcas gene) or considerably younger than the first known fossil records for many of these groups highlights the need for extreme caution in interpretation of classical molecular clock estimates for these groups. Many calibrations for subgroups with less dense fossil records will yield estimates that are not clearly 
TABLE 2-Mean molecular clock divergence time estimates and standard errors, based on Kimura 2 parameter distances for the nuclear kappa casein gene, using multiple calibration points. Values to the lower left are divergence time estimates, on upper right are standard errors. Top to bottom, calibrations are 1, 5, 6, 7, 8, (see Table 1). Whole cells marked N/A could not be calculated because all taxa violated relative rates tests; individual N/A values represent the calibration date.

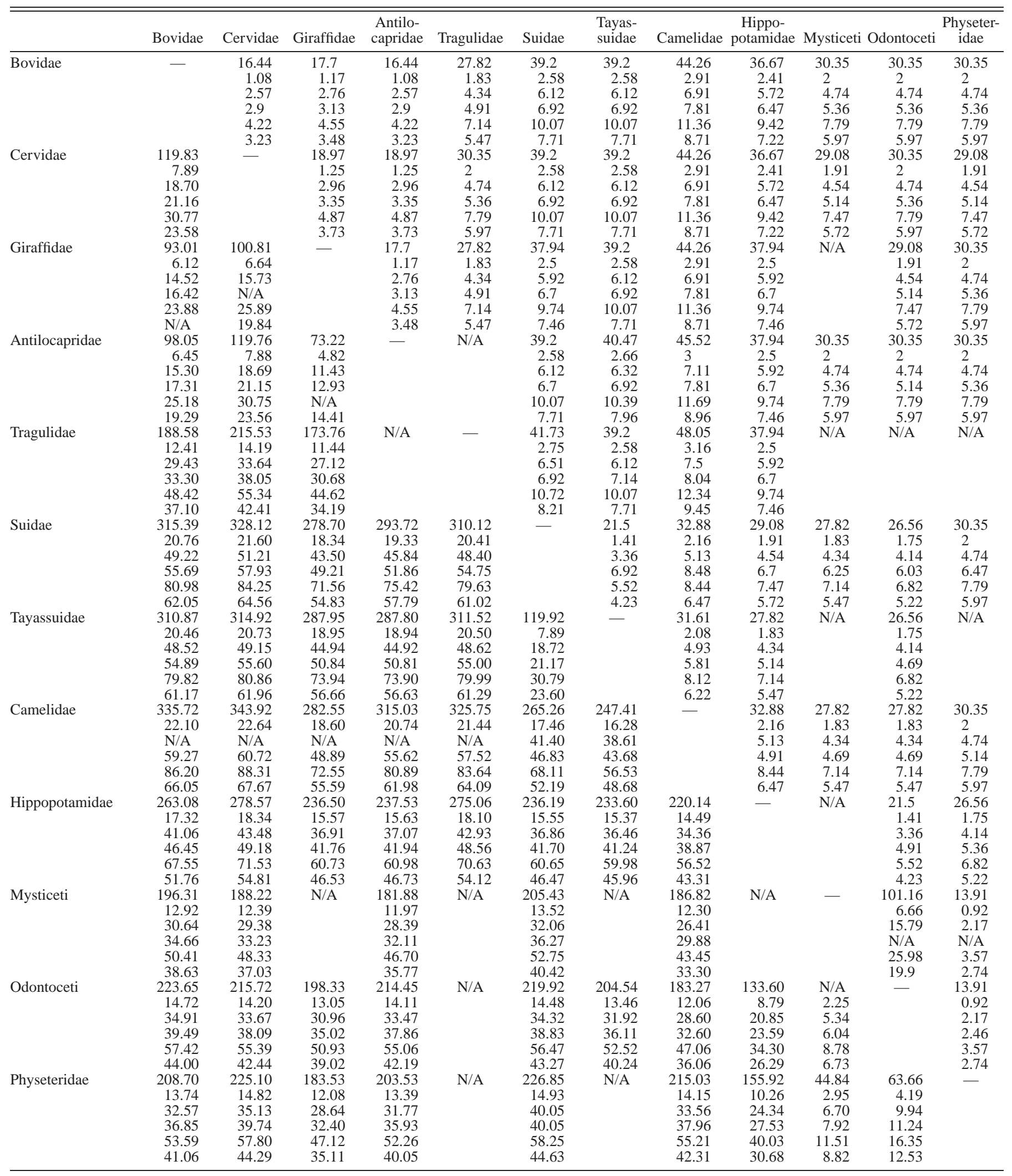




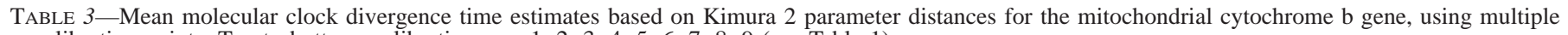
calibration points. Top to bottom, calibrations are $1,2,3,4,5,6,7,8,9$ (see Table 1).

\begin{tabular}{|c|c|c|c|c|c|c|c|c|c|c|c|c|}
\hline & Bovidae & Cervidae & Giraffidae & $\begin{array}{c}\text { Antilo- } \\
\text { capridae }\end{array}$ & Tragulidae & Suidae & $\begin{array}{l}\text { Tayas- } \\
\text { suidae }\end{array}$ & Camelidae & $\begin{array}{c}\text { Hippo- } \\
\text { potamidae }\end{array}$ & Mysticeti & Odontoceti & $\begin{array}{l}\text { Physeter- } \\
\text { idae }\end{array}$ \\
\hline \multirow[t]{9}{*}{ Bovidae } & - & 1.5 & 1.88 & 1.69 & 2.07 & 2.07 & 2.07 & 2.07 & 2.07 & 2.07 & 2.07 & 2.25 \\
\hline & & 0.91 & 1.14 & 1.02 & 1.25 & 1.25 & 1.25 & 1.25 & 1.25 & 1.25 & 1.25 & 1.36 \\
\hline & & 1.29 & 1.61 & 1.45 & 1.77 & 1.77 & 1.77 & 1.77 & 1.77 & 1.77 & 1.77 & 1.93 \\
\hline & & 2.26 & 2.82 & 2.54 & 3.1 & 3.1 & 3.1 & 3.1 & 3.1 & 3.1 & 3.1 & 3.38 \\
\hline & & 0.51 & 0.64 & 0.58 & 0.71 & 0.71 & 0.71 & 0.71 & 0.71 & 0.71 & 0.71 & 0.77 \\
\hline & & 1.69 & 2.11 & 1.9 & 2.32 & 2.32 & 2.32 & 2.32 & 2.32 & 2.32 & 2.32 & 2.53 \\
\hline & & 0.86 & 1.07 & 0.97 & 1.18 & 1.18 & 1.18 & 1.18 & 1.18 & 1.18 & 1.18 & 1.29 \\
\hline & & 1.06 & 1.33 & 1.19 & 1.46 & 1.46 & 1.46 & 1.46 & 1.46 & 1.46 & 1.46 & 1.59 \\
\hline & & 0.85 & 1.06 & 0.96 & 1.17 & 1.17 & 1.17 & 1.17 & 1.17 & 1.17 & 1.17 & 1.27 \\
\hline \multirow{9}{*}{ Cervidae } & 31.76 & - & 2.07 & 1.88 & 2.25 & 2.25 & 2.25 & 2.44 & 2.44 & 2.25 & 2.25 & 2.63 \\
\hline & 19.23 & & 1.25 & 1.14 & 1.36 & 1.36 & 1.36 & 1.48 & 1.48 & 1.36 & 1.36 & 1.59 \\
\hline & 27.18 & & 1.77 & 1.61 & 1.93 & 1.93 & 1.93 & 2.09 & 2.09 & 1.93 & 1.93 & 2.25 \\
\hline & 47.70 & & 3.1 & 2.82 & 3.38 & 3.38 & 3.38 & 3.67 & 3.67 & 3.38 & 3.38 & 3.95 \\
\hline & 10.88 & & 0.71 & 0.64 & 0.77 & 0.77 & 0.77 & 0.84 & 0.84 & 0.77 & 0.77 & 0.9 \\
\hline & 35.64 & & 2.32 & 2.11 & 2.53 & 2.53 & 2.53 & 2.74 & 2.74 & 2.53 & 2.53 & 2.95 \\
\hline & 18.18 & & 1.18 & 1.07 & 1.29 & 1.29 & 1.29 & 1.4 & 1.4 & 1.29 & 1.29 & 1.5 \\
\hline & 22.43 & & 1.46 & 1.33 & 1.59 & 1.59 & 1.59 & 1.72 & 1.72 & 1.59 & 1.59 & 1.86 \\
\hline & 17.96 & & 1.17 & 1.06 & 1.27 & 1.27 & 1.27 & 1.38 & 1.38 & 1.27 & 1.27 & 1.49 \\
\hline \multirow{9}{*}{ Giraffidae } & 32.36 & 31.10 & - & 2.25 & 2.63 & 2.63 & 2.82 & 2.82 & 2.63 & 2.44 & 2.44 & 2.63 \\
\hline & 19.59 & 18.83 & & 1.36 & 1.59 & 1.59 & 1.71 & 1.71 & 1.59 & 1.48 & 1.48 & 1.59 \\
\hline & 27.68 & 26.61 & & 1.93 & 2.25 & 2.25 & 2.41 & 2.41 & 2.25 & 2.09 & 2.09 & 2.25 \\
\hline & 48.59 & 46.70 & & 3.38 & 3.95 & 3.95 & 4.23 & 4.23 & 3.95 & 3.67 & 3.67 & 3.95 \\
\hline & 11.09 & 10.66 & & 0.77 & 0.9 & 0.9 & 0.97 & 0.97 & 0.9 & 0.84 & 0.84 & 0.9 \\
\hline & 36.31 & 34.90 & & 2.53 & 2.95 & 2.95 & 3.16 & 3.16 & 2.95 & 2.74 & 2.74 & 2.95 \\
\hline & 18.52 & N/A & & 1.29 & 1.5 & 1.5 & 1.61 & 1.61 & 1.5 & 1.4 & 1.4 & 1.5 \\
\hline & 22.85 & 21.96 & & 1.59 & 1.86 & 1.86 & 1.99 & 1.99 & 1.86 & 1.72 & 1.72 & 1.86 \\
\hline & N/A & 17.59 & & 1.27 & 1.49 & 1.49 & 1.59 & 1.59 & 1.49 & 1.38 & 1.38 & 1.49 \\
\hline \multirow[t]{9}{*}{ Antilocapridae } & 27.59 & 29.20 & 26.63 & - & 2.25 & 2.25 & 2.44 & 2.44 & 2.63 & 2.44 & 2.25 & 2.63 \\
\hline & 16.70 & 17.68 & 16.12 & & 1.36 & 1.36 & 1.48 & 1.48 & 1.59 & 1.48 & 1.36 & 1.59 \\
\hline & 23.61 & 24.99 & 22.78 & & 1.93 & 1.93 & 2.09 & 2.09 & 2.25 & 2.09 & 1.93 & 2.25 \\
\hline & 41.43 & 43.85 & 39.98 & & 3.38 & 3.38 & 3.67 & 3.67 & 3.95 & 3.67 & 3.38 & 3.95 \\
\hline & 9.45 & 10.01 & 9.12 & & 0.77 & 0.77 & 0.84 & 0.84 & 0.9 & 0.84 & 0.77 & 0.9 \\
\hline & 30.96 & 32.77 & 29.88 & & 2.53 & 2.53 & 2.74 & 2.74 & 2.95 & 2.74 & 2.53 & 2.95 \\
\hline & 15.79 & 16.71 & 15.24 & & 1.29 & 1.29 & 1.4 & 1.4 & 1.5 & 1.4 & 1.29 & 1.5 \\
\hline & 19.48 & 20.62 & N/A & & 1.59 & 1.59 & 1.72 & 1.72 & 1.86 & 1.72 & 1.59 & 1.86 \\
\hline & 15.61 & 16.52 & 15.06 & & 1.27 & 1.27 & 1.38 & 1.38 & 1.49 & 1.38 & 1.27 & 1.49 \\
\hline \multirow[t]{9}{*}{ Tragulidae } & 39.12 & 42.27 & 38.78 & 34.08 & - & 2.25 & 2.63 & 2.44 & 2.44 & & 2.44 & 2.82 \\
\hline & 23.68 & 25.59 & 23.47 & 20.63 & & 1.36 & 1.59 & 1.48 & 1.48 & & 1.48 & 1.71 \\
\hline & 33.47 & 36.16 & 33.18 & 29.16 & & 1.93 & 2.25 & 2.09 & 2.09 & & 2.09 & 2.41 \\
\hline & 58.74 & 63.47 & 58.23 & 51.17 & & 3.38 & 3.95 & 3.67 & 3.67 & & 3.67 & 4.23 \\
\hline & 13.40 & 14.48 & 13.29 & 11.68 & & 0.77 & 0.9 & 0.84 & 0.84 & & 0.84 & 0.97 \\
\hline & 43.90 & 47.43 & 43.52 & 38.24 & & 2.53 & 2.95 & 2.74 & 2.74 & & 2.74 & 3.16 \\
\hline & 22.39 & 24.19 & 22.19 & 19.50 & & 1.29 & 1.5 & 1.4 & 1.4 & & 1.4 & 1.61 \\
\hline & 27.62 & 29.85 & 27.38 & 24.06 & & 1.59 & 1.86 & 1.72 & 1.72 & & 1.72 & 1.99 \\
\hline & 22.12 & & 21.93 & 19.27 & & 1.27 & 1.49 & 1.38 & 1.38 & & 1.38 & 1.59 \\
\hline \multirow{9}{*}{ Suidae } & 40.30 & 41.81 & N/A & 33.28 & 42.78 & - & 2.25 & 2.25 & 2.44 & 2.25 & 2.25 & 2.44 \\
\hline & 24.40 & 25.31 & & 20.15 & 25.90 & & 1.36 & 1.36 & 1.48 & 1.36 & 1.36 & 1.48 \\
\hline & 34.48 & 35.77 & & 28.48 & 36.60 & & 1.93 & 1.93 & 2.09 & 1.93 & 1.93 & 2.09 \\
\hline & 60.51 & 62.78 & & 49.98 & 64.24 & & 3.38 & 3.38 & 3.67 & 3.38 & 3.38 & 3.67 \\
\hline & 13.81 & 14.33 & & 11.40 & 14.66 & & 0.77 & 0.77 & 0.84 & 0.77 & 0.77 & 0.84 \\
\hline & 45.22 & 46.91 & & 37.34 & 48.01 & & 2.53 & 2.53 & 2.74 & 2.53 & 2.53 & 2.74 \\
\hline & 23.06 & 23.93 & & 19.05 & 24.48 & & 1.29 & 1.29 & 1.4 & 1.29 & 1.29 & 1.4 \\
\hline & 28.45 & 29.52 & & 23.50 & 30.21 & & 1.59 & 1.59 & 1.72 & 1.59 & 1.59 & 1.72 \\
\hline & 22.79 & 23.64 & & 18.82 & 24.20 & & 1.27 & 1.27 & 1.38 & 1.27 & 1.27 & 1.38 \\
\hline Tayassuidae & 38.69 & 40.88 & 40.39 & 33.32 & 43.50 & 35.75 & - & 2.63 & 2.63 & & 2.44 & 2.82 \\
\hline & 23.42 & 24.75 & 24.45 & 20.17 & 26.33 & 21.64 & & 1.59 & 1.59 & & 1.48 & 1.71 \\
\hline & 33.10 & 34.97 & 34.55 & 28.51 & 37.21 & 30.56 & & 2.25 & 2.25 & & 2.09 & 2.41 \\
\hline & 58.10 & 61.38 & 60.64 & 50.03 & 65.31 & 53.69 & & 3.95 & 3.95 & & 3.67 & 4.23 \\
\hline & 13.26 & 14.01 & 13.84 & 11.42 & 14.90 & 12.25 & & 0.9 & 0.9 & & 0.84 & 0.97 \\
\hline & 43.41 & 45.87 & 45.32 & 37.39 & 48.81 & 40.12 & & 2.95 & 2.95 & & 2.74 & 3.16 \\
\hline & 22.14 & 23.39 & 23.11 & 19.07 & 24.89 & 20.46 & & 1.5 & 1.5 & & 1.4 & 1.61 \\
\hline & 27.32 & 28.86 & 28.52 & 23.53 & 30.71 & 25.24 & & 1.86 & 1.86 & & 1.72 & 1.99 \\
\hline & 21.88 & 23.12 & 22.84 & 18.84 & 24.60 & 20.22 & & 1.49 & 1.49 & & 1.38 & 1.59 \\
\hline Camelidae & 45.85 & 48.17 & 46.79 & 44.27 & 47.54 & 44.80 & 48.76 & - & 2.44 & 2.44 & 2.44 & 2.63 \\
\hline & 27.76 & 29.16 & 28.32 & 26.80 & 28.78 & 27.12 & 29.52 & & 1.48 & 1.48 & 1.48 & 1.59 \\
\hline & 39.23 & 41.21 & 40.03 & 37.87 & 40.67 & 38.33 & 41.72 & & 2.09 & 2.09 & 2.09 & 2.25 \\
\hline & 68.84 & 72.32 & 70.26 & 66.47 & 71.38 & 67.27 & 73.22 & & 3.67 & 3.67 & 3.67 & 3.95 \\
\hline & 15.71 & 16.50 & 16.03 & 15.17 & 16.29 & 15.35 & 16.71 & & 0.84 & 0.84 & 0.84 & 0.9 \\
\hline & 51.45 & 54.05 & 52.50 & 49.67 & 53.34 & 50.27 & 54.72 & & 2.74 & 2.74 & 2.74 & 2.95 \\
\hline & 26.24 & 27.57 & 26.78 & 25.33 & 27.21 & 25.64 & 27.91 & & 1.4 & 1.4 & 1.4 & 1.5 \\
\hline & 32.37 & 34.00 & 33.04 & 31.26 & 33.56 & 31.63 & 34.43 & & 1.72 & 1.72 & 1.72 & 1.86 \\
\hline & 25.93 & 27.24 & 26.46 & 25.04 & 26.88 & 25.33 & 27.58 & & 1.38 & 1.38 & 1.38 & 1.49 \\
\hline
\end{tabular}


TABLE 3-Continued.

\begin{tabular}{|c|c|c|c|c|c|c|c|c|c|c|c|c|}
\hline & Bovidae & Cervidae & Giraffidae & $\begin{array}{l}\text { Antilo- } \\
\text { capridae }\end{array}$ & Tragulidae & Suidae & $\begin{array}{l}\text { Tayas- } \\
\text { suidae }\end{array}$ & Camelidae & $\begin{array}{c}\text { Hippo- } \\
\text { potamidae }\end{array}$ & Mysticeti & Odontoceti & $\begin{array}{c}\text { Physeter- } \\
\text { idae }\end{array}$ \\
\hline \multirow[t]{9}{*}{ Hippopotamidae } & 42.53 & 44.65 & 44.12 & 38.64 & 47.09 & N/A & 40.07 & 48.62 & - & 2.44 & 2.25 & 2.63 \\
\hline & 25.75 & 27.04 & 26.71 & 23.39 & 28.51 & & 24.26 & 29.43 & & 1.48 & 1.36 & 1.59 \\
\hline & 36.39 & 38.20 & 37.75 & 33.06 & 40.29 & & 34.28 & 41.59 & & 2.09 & 1.93 & 2.25 \\
\hline & 63.86 & 67.05 & 66.25 & 58.03 & 70.71 & & 60.17 & 73.00 & & 3.67 & 3.38 & 3.95 \\
\hline & 14.57 & 15.30 & 15.12 & 13.24 & 16.14 & & 13.73 & 16.66 & & 0.84 & 0.77 & 0.9 \\
\hline & 47.72 & 50.11 & 49.51 & 43.36 & 52.84 & & 44.96 & 54.55 & & 2.74 & 2.53 & 2.95 \\
\hline & 24.34 & 25.55 & 25.25 & 22.17 & 26.95 & & 22.93 & 27.82 & & 1.4 & 1.29 & 1.5 \\
\hline & 30.03 & 31.53 & 31.15 & 27.28 & 33.25 & & 28.29 & 34.33 & & 1.72 & 1.59 & 1.86 \\
\hline & 24.05 & 25.25 & 24.95 & 21.85 & 26.63 & & 22.66 & 27.49 & & 1.38 & 1.27 & 1.49 \\
\hline \multirow[t]{9}{*}{ Mysticeti } & 41.67 & 44.70 & 41.17 & 38.54 & 46.03 & 41.45 & 40.74 & 48.21 & 40.61 & - & 1.69 & 1.69 \\
\hline & 25.22 & 27.06 & 24.92 & 23.33 & 27.86 & 25.09 & 24.66 & 29.18 & 24.58 & & 1.02 & 1.02 \\
\hline & 35.65 & 38.24 & 35.22 & 32.97 & 39.38 & 35.46 & 34.86 & 41.24 & 34.74 & & 1.45 & 1.45 \\
\hline & 62.57 & 67.12 & 61.81 & 57.87 & 69.11 & 62.23 & 61.18 & 72.39 & 60.97 & & 2.54 & 2.54 \\
\hline & 14.28 & 15.32 & 14.11 & 13.21 & 15.77 & 14.20 & 13.96 & 16.52 & 13.91 & & 0.58 & 0.58 \\
\hline & 46.76 & 50.16 & 46.19 & 43.24 & 51.65 & 46.51 & 45.72 & 54.09 & 45.56 & & 1.9 & 1.9 \\
\hline & 23.85 & 25.58 & 23.56 & 22.06 & 26.34 & 23.72 & 23.32 & 27.59 & 23.24 & & 0.97 & 0.97 \\
\hline & 29.42 & 31.56 & 29.07 & 27.21 & 32.50 & 29.26 & 28.77 & 34.04 & 28.67 & & 1.19 & 1.19 \\
\hline & 23.56 & 25.28 & 23.28 & 21.79 & 26.03 & 23.44 & 23.04 & 27.26 & 22.96 & & 0.96 & 0.96 \\
\hline \multirow{9}{*}{ Odontoceti } & 45.24 & 46.97 & 45.80 & 41.85 & 49.38 & 47.26 & 45.85 & 52.01 & 44.92 & N/A & - & 1.69 \\
\hline & 27.38 & 28.44 & 27.73 & 25.34 & 29.89 & 28.61 & 27.76 & 31.49 & 27.19 & 20.70 & & 1.02 \\
\hline & 38.70 & 40.19 & 39.19 & 35.81 & 42.24 & 40.34 & 39.23 & 44.50 & 38.43 & 29.26 & & 1.45 \\
\hline & 67.93 & 70.53 & 68.78 & 62.85 & 74.14 & 70.97 & 68.85 & 78.10 & 67.45 & 51.35 & & 2.54 \\
\hline & 15.5 & 16.09 & 15.69 & 14.34 & 16.92 & 16.20 & 15.71 & 17.82 & 15.39 & 11.72 & & 0.58 \\
\hline & 50.76 & 52.71 & 51.40 & 46.97 & 55.41 & 53.04 & 51.45 & 58.36 & 50.41 & 38.38 & & 1.9 \\
\hline & 25.89 & 26.88 & 26.21 & 23.95 & 28.26 & 27.05 & 26.24 & 29.77 & 25.71 & 19.57 & & 0.97 \\
\hline & 31.94 & 33.17 & 32.34 & 29.55 & 34.86 & 33.37 & 32.37 & 36.72 & 31.72 & 24.15 & & 1.19 \\
\hline & 25.58 & 26.56 & 25.90 & 23.67 & 27.92 & 26.73 & 25.93 & 29.41 & 25.40 & 19.34 & & 0.96 \\
\hline \multirow[t]{9}{*}{ Physeteridae } & 45.68 & 47.10 & 46.20 & 41.05 & 50.43 & N/A & N/A & 52.82 & 44.44 & 31.85 & 36.92 & - \\
\hline & 27.65 & 28.51 & 27.97 & 24.85 & 30.53 & & & 31.97 & 26.90 & 19.28 & 22.35 & \\
\hline & 39.08 & 40.29 & 39.53 & 35.12 & 43.14 & & & 45.19 & 38.02 & 27.25 & 31.59 & \\
\hline & 68.59 & 70.72 & 69.38 & 61.64 & 75.72 & & & 79.31 & 66.73 & 47.83 & 55.44 & \\
\hline & 15.65 & 16.14 & 15.83 & 14.07 & 17.28 & & & 18.10 & 15.23 & 10.91 & 12.65 & \\
\hline & 51.26 & 52.85 & 51.84 & 46.07 & 56.58 & & & 59.27 & 49.87 & 35.74 & 41.43 & \\
\hline & 26.14 & 26.95 & 26.44 & 23.49 & 28.86 & & & 30.23 & 45.43 & 18.23 & 21.13 & \\
\hline & 32.25 & 33.25 & 32.62 & 28.99 & 35.60 & & & 37.29 & 31.38 & 22.45 & 26.07 & \\
\hline & 25.83 & 26.63 & 26.13 & 23.22 & 28.52 & & & 29.87 & 25.13 & 18.01 & 20.88 & \\
\hline
\end{tabular}

untenable and yet are likely to be erroneous, and there is little basis on which to reject such calibrations a priori.

Further, the fact that many comparisons in this analysis passed a relative rates test, and yet the molecular clock assumption was rejected by a likelihood ratio test, indicates that there is significant rate variation in these sequences that would not be detected under traditional relative rates tests (Bromham et al., 2000; Robinson et al., 1998; Sorhannus and Van Bell, 1999; Tourasse and Li, 1999). It is apparent that reliable molecular clock estimates for this group cannot be made without considerable care in methodology. A better approach for using molecular clocks within Cetartiodactyla is likely to be using another clock method, such as a Bayesian approach, where relaxed assumptions of clocklike behavior can be incorporated into the evolutionary model, along with using additional genes. Given the similar problems with calibration noted in using quartet dating (Brochu, this volume), that approach would not be recommended for these data.

The results of this analysis show that additional work is needed on these groups before molecular clock estimates can be used reliably in conjunction with studies of fossils to clarify the evolutionary history of artiodactyls and whales. The current molecular phylogenies imply considerably earlier divergences than we know from the fossil record, but rate variation in the genes examined and difficulties in choosing a calibration preclude the estimates in Tables 2-3 from being regarded as reliable.

TABLE 4-First appearance data for taxa examined.

\begin{tabular}{|c|c|c|c|}
\hline Taxon & First fossil known & Age & Reference \\
\hline Bovidae & Eotragus & $18.3 \mathrm{Ma}$ & Solounias et al., 1995 \\
\hline Cervidae & Lagomeryx or other muntiacines & Early Miocene & McKenna and Bell, 1997 \\
\hline Giraffidae & Canthumeryx & $17.8 \mathrm{Ma}$ & Drake et al., 1988 \\
\hline Antilocapridae & Merycodontids & $18.3 \mathrm{Ma}$ & Janis et al., 1998 \\
\hline Tragulidae & Dorcatherium & Early Miocene & McKenna and Bell, 1997 \\
\hline Suidae & Palaeochoerus & Oligocene & McKenna and Bell, 1997 \\
\hline Tayassuidae & Perchoerus & Late Eocene & Janis et al., 1998 \\
\hline Camelidae & Poebrodon & $45-46 \mathrm{Ma}$ & Janis et al., 1998 \\
\hline Hippopotamidae & Kenyapotamus & $15.6-15.8 \mathrm{Ma}$ & Behrensmeyer et al., 2002 \\
\hline Mysticeti & Llanocetus & $34.2 \mathrm{Ma}$ & Fordyce, 1989 \\
\hline Odontoceti & Unnamed & $34-35 \mathrm{Ma}$ & Barnes and Goedert, 2000 \\
\hline Physeteridae & Ferecetotherium & Late Oligocene & Fordyce and Barnes, 1994 \\
\hline Cetacea & Himalayacetus & $53.5 \mathrm{Ma}$ & Bajpai and Gingerich, 1998 \\
\hline Artiodactyla & Diacodexis & $55 \mathrm{Ma}$ & Gingerich, 1989 \\
\hline
\end{tabular}




\section{REFERENCES}

Arnason, U., AND A. Gullberg. 1996. Cytochrome $b$ nucleotide sequences and the identification of five primary lineages of extant cetaceans. Molecular Biology and Evolution, 13(2):407-417.

BAJPAi, S., AND P. D. GingERICH. 1998. A new Eocene archaeocete (Mammalia, Cetacea) from India and the time of origin of whales. Proceedings of the National Academy of Sciences, 95(26):15464-15468.

BARnes, L. G., AND J. L. GoEdert. 2000. The world's oldest known odontocete (Mammalia: Cetacea). Journal of Vertebrate Paleontology, 20(Supplement to No. 3):28A.

Behrensmeyer, A. K., A. L. Deino, A. Hill, J. D. Kingston, and J. J. SAunders. 2002. Geology and geochronology of the middle Miocene Kipsaramon site complex, Muruyur Beds, Tugen Hills, Kenya. Journal of Human Evolution, 42:11-38.

Berta, A., C. E. RAY, AND A. R. WYSS. 1989. Skeleton of the oldest known pinniped, Enaliarctos mealsi. Science, 244:60-62.

Bromham, L., D. Penny, A. Rambaut, and M. D. Hendy. 2000. The power of relative rates tests depends on the data. Journal of Molecular Evolution, 50(3):296-301.

Colbert, E. H. 1935. Distributional and phylogenetic studies on Indian fossil mammals. IV. The phylogeny of the Indian Suidae and the origin of the Hippopotamidae. American Museum Novitates, 799:1-24.

Drake, R. E., J. A. Van Couvering, M. Pickford, G. H. Curtis, And J. A. HARris. 1988. New chronology for the Early Miocene mammalian faunas of Kisingiri, western Kenya. Journal of the Geological Society, London, 145:479-491.

FELSENSTEIN, J. 1981. Evolutionary trees from DNA sequences: a maximum likelihood approach. Journal of Molecular Evolution, 17:368-376.

FITCH, W. M. 1976. Molecular evolutionary clocks, p. 160-178. In F. J. Ayala (ed.), Molecular Evolution. Sinauer Associates, Sunderland, Massachusetts.

FORDYCE, R. E. 1989. Origins and evolution of Antarctic marine mammals. Special Publication of the Geological Society, London, 47:269-281.

FordyCE, R. E., AND L. G. BARNES. 1994. The evolutionary history of whales and dolphins. Annual Review of Earth and Planetary Sciences, 22:419-455.

GAtesy, J. 1997. More DNA support for a Cetacea/Hippopotamidae clade: the blood clotting protein gene $\gamma$-fibrinogen. Molecular Biology and Evolution, 14(5):537-543.

GAtesy, J. 1998. Molecular evidence for the phylogenetic affinities of Cetacea, p. 63-111. In J. G. M. Thewissen (ed.), The Emergence of Whales: Evolutionary Patterns in the Origin of Cetacea. Plenum Press, New York and London.

Gatesy, J., C. Hayashi, M. A. Cronin, and P. Arctander. 1996. Evidence from milk casein genes that cetaceans are close relatives of hippopotamid artiodactyls. Molecular Biology and Evolution, 13(7): 954-963.

Gatesy, J., M. Milinkovitch, V. Waddell, and M. Stanhope. 1999. Stability of cladistic relationships between Cetacea and higher-level artiodactyl taxa. Systematic Biology, 48(1):6-20.

GINGERICH, P. D. 1989. New earliest Wasatchian mammalian fauna from the Eocene of Northwestern Wyoming: composition and diversity in a rarely sampled high-floodplain assemblage. University of Michigan Papers in Paleontology, 28:1-97.

Gingerich, P. D., M. ul HaQ, I. S. Zalmout, I. H. Khan, And M. S. MALKANI. 2001. Origin of whales from early artiodactyls: hands and feet of Eocene Protocetidae from Pakistan. Science, 293:2239-2242.

Graur, D., AND D. G. Higgins. 1994. Molecular evidence for the inclusion of cetaceans within the Order Artiodactyla. Molecular Biology and Evolution, 11(3):357-364.

Huchon, D., F. M. CATZEFlis, And E. J. P. Douzery. 2000. Variance of molecular datings, evolution of rodents and the phylogenetic affinities between Ctenodactylidae and Hystricognathi. Proceedings of the Royal Society, London, Series B, Biological Science, 267(1441):393-402.

Huelsenbeck, J. P., AND K. A. CRAndall. 1997. Phylogeny estimation and hypothesis testing using maximum likelihood. Annual Review of Ecology and Systematics, 28:437-466.

Huelsenbeck, J. P., and B. Rannala. 1997. Phylogenetic methods come of age: testing hypotheses in an evolutionary context. Science, 276:227-232.

JACOBS, L. L., AND W. R. Downs. 1994. The evolution of murine rodents in Asia. In Y. Tomida, C. Li, and T. Setoguchi (eds.), Rodents and
Lagomorph Families of Asian Origin and Diversification. National Science Museum Monograph, Tokyo, Japan.

Janis, C. M., K. M. SCOTT, AND L. L. JacoBs. 1998. Evolution of Tertiary Mammals of North America, Volume 1, Terrestrial Carnivores, Ungulates, and Ungulatelike Mammals. Cambridge University Press, Cambridge, United Kingdom.

Kumar, S., And B. S. Hedges. 1998. A molecular timescale for vertebrate evolution. Nature, 392:917-920.

Marshall, C. R. 1990. Confidence intervals on stratigraphic ranges Paleobiology, 16:1-10.

McKenna, M. C., And S. K. Bell. 1997. Classification of Mammals Above the Species Level. Columbia University Press, New York.

Milinkovitch, M. C., M. Bérubé, AND P. J. PALsbøll. 1998. Cetaceans are highly derived artiodactyls, p. 113-131. In J. G. M. Thewissen (ed.), The Emergence of Whales: Evolutionary Patterns in the Origin of Cetacea. Plenum Press, New York and London.

Nikaido, M., F. Matsuno, H. Hamilton, R. L. Brownell, Y. CaO, W. Ding, Z. Zuoyan, A. M. Shedlock, R. E. Fordyce, M. Hasegawa, AND N. OKADA. 2001. Retroposon analysis of major cetacean lineages: the monophyly of toothed whales and the paraphyly of river dolphins Proceedings of the National Academy of Sciences, 98(13):7384-7389.

Nikaido, M. A., P. RoOney, AND N. OKadA. 1999. Phylogenetic relationships among cetartiodactyls based on insertions of short and long interpersed elements: Hippopotamuses are the closest extant relatives of whales. Proceedings of the National Academy of Sciences, 96: $10261-10266$.

Norman, J. E., AND M. V. Ashley. 2000. Phylogenetics of Perissodactyla and tests of the molecular clock. Journal of Molecular Evolution, 50(1):11-21.

PeARSON, H. S. 1927. On the skulls of early Tertiary Suidae, together with an account of the otic region in some other primitive Artiodactyla. Philosophical Transactions of the Royal Society, London, CCXV(B):389-460

PICKFORD, M. 1983. On the origins of the Hippopotamidae together with descriptions of two new species, a new genus and a new subfamily from the Miocene of Kenya. Géobios, 16:193-217.

Posada, D., AND K. A. Crandall. 1998. MODElTEST: testing the model of DNA substitution. Bioinformatics, 14(9):817-818.

Robinson, M., M. Gouy, C. Gautier, AND D. Mouchiroud. 1998. Sensitivity of the relative-rate test to taxonomic sampling. Molecular Biology and Evolution, 15(9):1091-1098.

SARICH, V. M., AND A. C. WILSON. 1967. Immunological time scale for hominid evolution. Science, 158:1200-1203.

Savage, D. E., AND D. E. Russell. 1983. Mammalian Paleofaunas of the World. Addison-Wesley, Reading, Massachusetts.

Solounias, N., J. C. BarRy, R. L. Bernor, E. H. Lindsay, and S. Mahmood Raza. 1995. The oldest bovid from the Siwaliks, Pakistan. Journal of Vertebrate Paleontology, 15(4):806-814.

Soltis, P. S., D. E. Soltis, V. Savolainen, P. R. Crane, and T. G. BARRACLOUGH. 2002. Rate heterogeneity among lineages of tracheophytes: integration of molecular and fossil data and evidence for molecular living fossils. Proceedings of the National Academy of Sciences, 99(7):4430-4435.

SoRHANNUS, U., AND C. VAN BELl. 1999. Testing for equality of molecular evolutionary rates: a comparison between a relative-rate test and a likelihood ratio test. Molecular Biology and Evolution, 16(6): $849-855$.

SwOFFORD, D. L. 1992. Phylogenetic Analysis Using Parsimony (PAUP). Illinois Natural History Survey, Champaign, Illinois.

Swofford, D. L., G. J. Olsen, P. J. Waddell, AND D. M. Hillis. 1996. Phylogenetic inference, p. 407-543. In D. M. Hillis, C. Moritz, and B. K. Mable (eds.), Molecular Systematics. Sinauer Associates, Sunderland, Massachusetts.

TAJIMA, F. 1993. Simple methods for testing the molecular clock hypothesis. Genetics, 135:599-607.

Thewissen, J. G. M., E. M. Williams, L. J. Roe, and S. T. Hussain. 2001. Skeletons of terrestrial cetaceans and the relationship of whales to artiodactyls. Nature, 413:277-281.

Tourasse, N. J., AND W.-H. LI. 1999. Performance of the relative-rate test under nonstationary models of nucleotide substitution. Molecular Biology and Evolution, 16(8):1068-1078.

Wayne, R. K., B. Van Valkenburgh, and S. J. O’Brien. 1991. Molecular distance and divergence time in carnivores and primates. Molecular Biology and Evolution, 8(3):297-319.

ACCEPTEd 15 August 2003 